\title{
Bibliometric analysis of Central European journals in the Web of Science and JCR Social Science Edition
}

\author{
Slavomír Bucher \\ Institute of Geography,Faculty of Science, \\ University of Pavol Josef Safárik, Košice, SLOVAKIA \\ e-mail: slavomir.bucher@kosice.sk
}

\begin{abstract}
This paper deals with the multi-perspective bibliometric analysis of Central European scientific journals indexed in the Web of Science database and covered in the Journal Citation Reports - Social Science Citation Index (SSCI). The analysis focuses on the evaluation of the (inter) national orientation of Central European Social Science journals indexed in the period 2012 - 2015. Data were obtained from the Web of Science database on October 20,2016. The journals are divided in two groups in favour of the scientific discipline identifying the journal in the Web of Science. The first group consists of journals belonged to public health and psychology. The second group includes all social related scientific journals covered in both the SSCl and Science Citation Index Expanded (SCIE) databases. Journals were chosen by language versions of journals in the Web of Science, language versions of articles, authors' most important institutional affiliations; and other statistically significant indicators provided by Clarivate Analytics. Assessment of the "openness of Central European journals" to foreign authors was analyzed on the basis of the "INO indicator" (Index of National Orientation). Statistical analyses were conducted on the articles which carry the relevant scientific information. Descriptive statistics was used for the data analysis, using frequencies, percentages and means. The results of this research showed a strong orientation towards Slovakian and Czech authors regardless of the two analyzed groups. Based on INO, most of the Central European journals quality and impact were comparatively low. A competitive environment has been created for journals in the social science disciplines, especially for those with competitors in neighboring countries in fields such as psychology, economics, geography and sociology.
\end{abstract}

Keywords: Web of Science; Bibliometrics; Central European Journals; Social Science journals; Indicator of National Orientation; Research assessment.

\section{INTRODUCTION}

Bibliometrics is a good tool for measuring research activity and performance and currently, the majority of researchers support the increasing use of bibliometric data for scientometrics assessment. Academic papers serve as a channel through which academics present the results of their research (and verified knowledge of teaching processes (Nederhof 2006; Moed 2010) and journal publications represent one of the main research indicators for academics around the world. However, bibliometric indicator is only one of many other equally important indicators of science and research quality. Journal abstracting and indexing services, as well as the actual processing of publications by global citation databases such as the Web of Science, are far away from completeness and reliability, even 
though the results are valuable and well interpretable (Mayur and Mabe 2004; Garfield 2006; Meho and Yang 2007; Bar-llan 2008; Varela 2013).

Bibliometric comparison of Central European journals may represent a useful journal evaluation tool for the journal editorial boards in the examined countries. A high number of Central European journals is represented in the Social Science Citation Index (SSCI). The journals are divided in two groups in favour of the scientific discipline identifying the journal in the Web of Science. The first group consists of journals belonged to public health and psychology. Two of them are published in Czech Republic - Central European Journal of Public Health and Czechoslovakia Psychology, one in Slovakia - Studia Psychologica, three in Poland - Advances in Cognitive Psychology, Nordic Studies on Alcohol and Drugs, and International Journal of Occupational Safety and Ergonomics, and one in Hungary - Journal of Behavioral Addictions. The second group includes all social related scientific journals covered in both the SSCl and Science Citation Index Expanded (SCIE) databases (Appendix).

One of the general indicator that determined the national or international journal orientation is language, in which volumes of the journal have been published to the wider academic community. English language represents a global leader in communication worldwide and serve as "lingua franca" in scientific research. The last two decades observe a gradual shift towards internationalization of many journals publishing their contributions to a local or regional level. Changing the publication rules policy or replacement national languages by English does not always resulted in increased quality of published articles or required citation quantity (Bloch and Walter 2001). As an example of recent changes in the publication policy rules is the Czech E \& M Ekonomie A Management which since 2014 has published articles not in Czech or Slovak languages but solely in English.

Thomson Reuters, the then owner of the Web of Science, in 2006 considered the possibility for more progressive indexing new journals from Central and Eastern Europe through an established framework program named "Regional Content Expansion in Web of Science: Opening Borders to Exploration". The expected objective was to enrich the database of regional studies that contribute to the development of scientific knowledge of the region. For this purpose, Thomson Reuters, has collected more than 10,000 publications covering all scientific disciplines, which was not included in the database Web of Science.

What does it mean for a local or a regional focused of Central European journals indexed in SSCI? The Central European region shares common cultural, historical and political heritage. Proximity of cultural and social behavioral patterns, as well as common sphere topics of interest among researchers who published in $\mathrm{SSCl}$ create conditions for cooperation in science and research. Indexation of the journals in $\mathrm{SSCl}$ may result in the increased attractiveness of Central European authors to publish their articles in the neighboring countries' journals. Due to common cultural and social interests, Central European journals are becoming potentially attractive to scientists from the wider region of Western and Eastern Europe.

Following the works dedicated to the bibliometric research in Central Europe (Zitt and Bassecoulard 1998; Hicks 1999; Siwek 2005; Vanclay 2012; Hofierka and Gallay 2013; Skovajsa 2014a), the survey is based on the well-chosen bibliometric indicators to analyze national and/or international orientation of Central European journals covered in the database Web of Science and Journal Citation Reports - Social Science Edition. For the purpose of this research, all Slovak, Czech, Polish and Hungarian social science related journals have been included in the assessment. 


\section{MATERIALS AND METHOD}

The study aims to contribute to potential readers interesting information regarding the comparison of social science journals in Central Europe covered by the SSCl citation index, based on data from the Web of Science database and Journal Citation Reports (JCR), covering the period $2012-2015$. For the purpose of this research, selected indicators were pursued, partly corresponding with: (a) the analysis of authors (Pulišelić and Petrak 2006; Maričić, 2007; Machaček and Kolcunová 2008); (b) language version of journal title referred in database Web of Science; (c) spatial differentiation of authors and co-authors according to their affiliation; (d) articles language version; (e) the most important institutions with authors affiliation of articles, and (f) other statistically significant indicators provided by Clarivate Analytics (previously the Intellectual Property and Science business of Thomson Reuters). An assessment of "Openness Central European Journals" to foreign authors was analyzed through the Indicator of National Orientation (INO). INO indicator is defined as a journal's share of papers from the most represented country in relation to the total number of published papers in the same journal. The higher value of indicator represents the national orientation of journal; on the other hand, the declining value of the indicator increases the share of international journal orientation. The sum of eleven Czech, three Slovak, eight Polish and five Hungarian journals can be found in citation indexes of $\mathrm{SSCl}$ and SCIE as part of JCR.

The data source for this research was obtained from the Web of Science on 20 October 2016. Only articles were considered, other resource types such as conference articles, book reviews, and editorial materials were excluded. Thus, data selection had been carried out based on the following criteria: title of the journal, while selecting articles reflected the chosen period of years indicated in methodological section of paper. Obtained results have been standardized and generalized to further processing and analyses. Throughout this paper outcomes productivity analysis has been used for identifying the address of the author(s), as the country of origin of author was referred to in various languages differently. In the case of inconsistent author identification, information on workplace address were obtained and compared with other publications in other bibliometric databases as well.

The method employed are described using various terms in the literature. The basic method could be termed comparative analysis of articles. The analysis included authors' addresses, productivity parameters (authors, institutions, year of publication, article type, language, journal) and citation. Recent studies in the field of bibliometric analysis especially in social sciences and humanities have pointed out to high share of publishing articles primarily oriented to local or regional topics (Makkonen and Mitze 2016; Abrizah, Xu and Nicholas 2017; Jurajda et al. 2017; Tang, Zhang and Naumann 2017). These topics are mostly published in journals and monographs with local or regional impact for limited number of readers. Based on drawn up analyzing of publications (Moed 2005) and spatial impact of journals indexed in the databases Clarivate Analytics has shown that publications covering all social and humanitarian disciplines in citation index $\mathrm{SSCl}$ have a higher index of national orientation in comparison with natural or technical disciplines. Furthermore, selected social science disciplines and their publications covered in $\mathrm{SSCl}$ (for example anthropology or psychology) show long-term trend for international orientation of processed articles.

When analyzing the data, the methodology employed in the following studies (Andreis and Jokić 2008; Laffan 2009; Bański 2012) was used, where the journals registered in the databases SSCl and SCIE were divided into two categories: (a) Social Sciences - Public Health and Psychology (SSM) and (b) Social Sciences - others (SSO). These researchers have 
established that journals in scientific disciplines such as psychology and public health achieve higher scores in following indicators: share of articles published in English, proportion of authors from the states representing Top 20, and lower values in the indicator of national orientation. They have a higher level of openness and internationalization compared to other social science journals.

\section{RESULTS AND DISCUSSION}

\section{Bibliometric Indicator Analysis of Central European Social Science Journals Indexed in the Web of Science}

Initial analyses show that a high number of journal publishers located their editorial office in the capital cities - Prague (Czech Republic, 9 out of 11), Bratislava (Slovakia, 3 out of 3 ), Budapest (Hungary 5, out of 5), and Warsaw (Poland, 3 out of 8 ). Other publishers have located their editorial offices outside the capital city, but in places with a rich academic background (Appendix).

The language of the journal title in Web of Science database is the first indicator which allows definition of the level of openness toward the authors from abroad. Information in the Appendix indicated that 8 journals stated its name in the local language, $(\mathrm{N}=9$, mainly Slovak and Czech journals). There is an interesting group of bilingual journals $(\mathrm{N}=3)$ that use a combined title in the local language and in English, for example, the Czech Sociological Review. Other journals state their titles in English only, while there is an exception for journals with primary Latin title such as Acta Oeconomica. The level of journal openness is evaluated alongside with language mutations of articles published in various volumes and issues. Five out of seven journals belonging to Public Health and Psychology (SSM) group published articles in the period from 2012 to 2015 only in English language (Table 1 - 4).

The more important category between the two belongs to the group Social Sciences - others (SSO), which integrate diverse socially oriented scientific disciplines such as economics, geography, political sciences, business and finance. This category is diverse in terms of language of the analyzed articles, as it was found that there are journals which publish exclusively in English and journals with local or regional topics in local languages. In analyzing the two categories of journals the following results were obtained:

a) The lowest proportion of English written articles belonged to Social Sciences journals - others (SSO), the highest proportion of English written articles have been recorded in Social Sciences category - Public health and psychology (SSM).

b) English language in the academic environment represents an essential communication engine across various scientific disciplines. Academics in Central Europe usually publish their papers in English, as well as high-quality Czech (Table 1), Slovak (Table 2), Polish (Table 3) and Hungarian journals (Table 4) normally accept articles in that language. 
Table 1: Number and Percentage of Papers Published in Different Languages in the Analyzed Czech Journals for the Period 2012-2015

\begin{tabular}{|c|c|c|c|c|c|c|c|}
\hline \multirow[t]{2}{*}{ Group of journals/titles } & \multirow{2}{*}{$\begin{array}{r}\text { Total } \\
\text { No of } \\
\text { papers }\end{array}$} & \multicolumn{2}{|c|}{$\begin{array}{c}\text { Czech } \\
\text { Language }\end{array}$} & \multicolumn{2}{|c|}{ English language } & \multicolumn{2}{|c|}{$\begin{array}{l}\text { Other languages } \\
\text { (mostly Slovak) }\end{array}$} \\
\hline & & $\begin{array}{r}\text { No } \\
\text { papers }\end{array}$ & $\%$ & $\begin{array}{r}\text { No } \\
\text { papers }\end{array}$ & $\%$ & $\begin{array}{r}\text { No } \\
\text { papers }\end{array}$ & $\%$ \\
\hline \multicolumn{8}{|l|}{$\begin{array}{l}\text { Journals registered in SSCI \& SCIE - Public health and } \\
\text { psychology } 2012-2015, \text { (SSM) }\end{array}$} \\
\hline CENTRAL EUROPEAN JOURNAL OF PUBLIC HEALTH & 220 & 0 & 0.0 & 220 & 100 & 0 & 0.0 \\
\hline CESKOSLOVENSKA PSYCHOLOGIE & 186 & 126 & 67.7 & 27 & 14.5 & 33 & 17.8 \\
\hline \multicolumn{8}{|l|}{$\begin{array}{l}\text { Journals registered in SSCI \& SCIE - others } 2012-2015 \text {, } \\
\text { (SSO) }\end{array}$} \\
\hline $\begin{array}{l}\text { AGRICULTURAL ECONOMICS-ZEMEDELSKA } \\
\text { EKONOMIKA }\end{array}$ & 222 & 0 & 0.0 & 222 & 100 & 0 & 0.0 \\
\hline E \& M EKONOMIE A MANAGEMENT & 198 & 50 & 25.3 & 148 & 74.7 & 0 & 0.0 \\
\hline $\begin{array}{l}\text { FINANCE A UVER-CZECH JOURNAL OF ECONOMICS AND } \\
\text { FINANCE }\end{array}$ & 98 & 0 & 0.0 & 98 & 100 & 0 & 0.0 \\
\hline GEOGRAFIE & 93 & 61 & 65.6 & 31 & 33.3 & 1 & 1.1 \\
\hline MORAVIAN GEOGRAPHICAL REPORTS & 86 & 0 & 0.0 & 86 & 100 & 0 & 0.0 \\
\hline POLITICKA EKONOMIE & 171 & 161 & 94.2 & 0 & 0.0 & 10 & 5.8 \\
\hline PRAGUE ECONOMIC PAPERS & 127 & 0 & 0.0 & 127 & 100 & 0 & 0.0 \\
\hline SOCIOLOGICKY CASOPIS-CZECH SOCIOLOGICAL REVIEW & 128 & 82 & 64.0 & 45 & 35.2 & 1 & 0.8 \\
\hline SLOVO A SLOVESNOST & 56 & 45 & 80.4 & 11 & 19.6 & 0 & 0.0 \\
\hline
\end{tabular}

Source: http://thomsonreuters.com/web-of-science-core-collection/ [accessible 20/10/2016].

Table 2: Number and Percentage of Papers Published in Different Languages in the Analyzed Slovak Journals for the Period 2012- 2015

\begin{tabular}{|c|c|c|c|c|c|c|c|}
\hline \multirow[t]{2}{*}{ Group of journals/titles } & \multirow{2}{*}{$\begin{array}{r}\text { Total } \\
\text { No of } \\
\text { papers }\end{array}$} & \multicolumn{2}{|c|}{$\begin{array}{c}\text { Slovak } \\
\text { Language }\end{array}$} & \multicolumn{2}{|c|}{ English language } & \multicolumn{2}{|c|}{$\begin{array}{l}\text { Other languages } \\
\text { (mostly Czech) }\end{array}$} \\
\hline & & $\begin{array}{r}\text { No } \\
\text { papers }\end{array}$ & $\%$ & $\begin{array}{r}\text { No } \\
\text { papers }\end{array}$ & $\%$ & $\begin{array}{r}\text { No } \\
\text { papers }\end{array}$ & $\%$ \\
\hline \multicolumn{8}{|c|}{$\begin{array}{l}\text { Journals registered SSCI \& SCIE - Public health and } \\
\text { psychology 2012-2015, (SSM) }\end{array}$} \\
\hline STUDIA PSYCHOLOGICA & 99 & 0 & 0.0 & 99 & 100 & 0 & 0.0 \\
\hline \multicolumn{8}{|c|}{$\begin{array}{l}\text { Journals registered in SSCI \& SCIE - others } 2012-2015 \text {, } \\
\text { (SSO) }\end{array}$} \\
\hline EKONOMICKY CASOPIS & 213 & 61 & 28.6 & 109 & 51.2 & 43 & 20.2 \\
\hline SOCIOLOGIA & 103 & 68 & 66.0 & 34 & 33.0 & 1 & 1.0 \\
\hline
\end{tabular}

Source: http://thomsonreuters.com/web-of-science-core-collection/ [accessible 20/10/2016]. 
Bucher, $S$.

Table 3: Number and Percentage of Papers Published in Different Languages in the Analyzed Polish Journals for the Period 2012 - 2015

\begin{tabular}{|c|c|c|c|c|c|c|c|}
\hline \multirow[t]{2}{*}{ Group of journals/titles } & \multirow{2}{*}{$\begin{array}{l}\text { Total } \\
\text { No of } \\
\text { papers }\end{array}$} & \multicolumn{2}{|c|}{$\begin{array}{c}\text { Polish } \\
\text { Language }\end{array}$} & \multicolumn{2}{|c|}{ English language } & \multicolumn{2}{|c|}{ Other languages } \\
\hline & & $\begin{array}{r}\text { No } \\
\text { papers }\end{array}$ & $\%$ & $\begin{array}{r}\text { No } \\
\text { papers }\end{array}$ & $\%$ & $\begin{array}{r}\text { No } \\
\text { papers } \\
\end{array}$ & $\%$ \\
\hline \multicolumn{8}{|l|}{$\begin{array}{l}\text { Journals registered in SSCI \& SCIE - Public health and } \\
\text { psychology } 2012-2015, \text { (SSM) }\end{array}$} \\
\hline $\begin{array}{l}\text { ADVANCES IN COGNITIVE PSYCHOLOGY } \\
\text { NORDIC STUDIES ON ALCOHOL AND DRUGS } \\
\text { INTERNATIONAL JOURNAL OF OCCUPATIONAL SAFETY } \\
\text { AND ERGONOMICS } \\
\end{array}$ & $\begin{array}{r}65 \\
116 \\
236\end{array}$ & $\begin{array}{l}0 \\
0 \\
0\end{array}$ & $\begin{array}{l}0.0 \\
0.0 \\
0.0\end{array}$ & $\begin{array}{r}65 \\
108 \\
236\end{array}$ & $\begin{array}{r}100 \\
93.1 \\
100\end{array}$ & $\begin{array}{l}0 \\
8 \\
0\end{array}$ & $\begin{array}{l}0.0 \\
6.9 \\
0.0\end{array}$ \\
\hline \multicolumn{8}{|l|}{$\begin{array}{l}\text { Journals registered SSCI \& SCIE - others } 2012-2015 \text {, } \\
\text { (SSO) }\end{array}$} \\
\hline PROBLEMY EKOROZWOJU & 110 & 18 & 16.4 & 92 & 83.6 & 0 & 0.0 \\
\hline EASTERN EUROPEAN COUNTRYSIDE & 33 & 0 & 0.0 & 33 & 100 & 0 & 0.0 \\
\hline ARGUMENTA OECONOMICA & 59 & 0 & 0.0 & 59 & 100 & 0 & 0.0 \\
\hline POZNAN STUDIES IN CONTEMPORARY LINGUISTICS & 89 & 0 & 0.0 & 89 & 100 & 0 & 0.0 \\
\hline POLISH SOCIOLOGICAL REVIEW & 115 & 0 & 0.0 & 115 & 100 & 0 & 0.0 \\
\hline
\end{tabular}

Source: http://thomsonreuters.com/web-of-science-core-collection/ [accessible 20/10/2016].

Table 4: Number and percentage of papers published in different languages in the analyzed Hungarian journals for the period $2012-2015$

\begin{tabular}{|c|c|c|c|c|c|c|c|}
\hline \multirow[t]{2}{*}{ Group of journals/titles } & \multirow{2}{*}{$\begin{array}{l}\text { Total } \\
\text { No of } \\
\text { papers }\end{array}$} & \multicolumn{2}{|c|}{$\begin{array}{l}\text { Hungarian } \\
\text { language }\end{array}$} & \multicolumn{2}{|c|}{ English language } & \multicolumn{2}{|c|}{ Other languages } \\
\hline & & $\begin{array}{r}\text { No } \\
\text { papers }\end{array}$ & $\%$ & $\begin{array}{r}\text { No } \\
\text { papers }\end{array}$ & $\%$ & $\begin{array}{r}\text { No } \\
\text { papers }\end{array}$ & $\%$ \\
\hline \multicolumn{8}{|c|}{$\begin{array}{l}\text { Journals registered in SSCI \& SCIE - Public health and } \\
\text { psychology 2012-2015, (SSM) }\end{array}$} \\
\hline JOURNAL OF BEHAVIORAL ADDICTIONS & 114 & 0 & 0.0 & 114 & 100 & 0 & 0.0 \\
\hline \multicolumn{8}{|c|}{$\begin{array}{l}\text { Journals registered in SSCI \& SCIE - others } 2012-2015 \text {, } \\
\text { (SSO) }\end{array}$} \\
\hline \multicolumn{4}{|l|}{ ACROSS LANGUAGES AND CULTURES } & 155 & & 0 & 0.0 \\
\hline CIVIL SZEMLE & 94 & 82 & 87.2 & 12 & 12.8 & 0 & 0.0 \\
\hline ACTA LINGUISTICA HUNGARICA & 59 & 0 & 0.0 & 59 & 100 & 0 & 0.0 \\
\hline
\end{tabular}

Source: http://thomsonreuters.com/web-of-science-core-collection/ [accessible 20/10/2016].

The following indicator monitors the spatial national/international localization of authors in the analyzed journals based on their affiliation. In case of Slovak journals (Table 5) authors from Slovakia are the most represented in both categories of the analyzed disciplines within the SSM journals, the share of articles published by Slovak authors is 35.4 percent $(\mathrm{N}=35)$, while in the SSO category, it is 49.4 percent $(N=156)$. Similar results were also observed by analyzing Czech journals with the only difference that the highest share of authors of the articles is represented by Czech authors (Table 5) 
Table 5: Number and Percentage of All Papers with Regards to the Country of Origin of the Authors and their Share in the Total Number of Published Papers for the Three Analyzed

Groups of Czech, Slovak, Polish and Hungarian Journals (2012 - 2015)

\begin{tabular}{|c|c|c|c|c|c|}
\hline \multirow{3}{*}{$\begin{array}{l}\text { Total No of papers } \\
\text { CZECH JOURNALS } \\
\text { Authors (with regards to their country of } \\
\text { origin) }\end{array}$} & \multicolumn{2}{|c|}{ SSM journals } & \multicolumn{3}{|c|}{ SSO journals } \\
\hline & \multicolumn{2}{|c|}{406} & \multicolumn{2}{|c|}{1179} & \\
\hline & No of papers & $\%$ & No of papers & $\%$ & \\
\hline Czech authors & 180 & 44.3 & 736 & 62.4 & \\
\hline Authors - Central Europe (PL, SK, HU) & 134 & 33.0 & 194 & 16.5 & \\
\hline out of authors from Slovakia & 91 & 22.4 & 134 & 11.4 & \\
\hline Authors from the TOP 20 countries & 99 & 24.4 & 186 & 15.8 & \\
\hline Authors from the rest of the world & 113 & 27.8 & 201 & 17.0 & \\
\hline Total No of papers & \multicolumn{2}{|c|}{ SSM journals } & \multicolumn{3}{|c|}{ SSO journals } \\
\hline SLOVAK JOURNALS & \multicolumn{2}{|c|}{99} & \multicolumn{3}{|c|}{316} \\
\hline $\begin{array}{l}\text { Authors (with regards to their country of } \\
\text { origin) }\end{array}$ & No of papers & $\%$ & No of papers & $\%$ & \\
\hline Slovak authors & 35 & 35.4 & 156 & 49.4 & \\
\hline Authors - Central Europe (CZ, PL, HU) & 22 & 22.2 & 151 & 47.8 & \\
\hline out of authors from Czech rep. & 8 & 8.1 & 143 & 45.3 & \\
\hline Authors from the TOP 20 countries & 25 & 25.3 & 19 & 6.0 & \\
\hline Authors from the rest of the world & 31 & 31.3 & 32 & 10.1 & \\
\hline \multirow{3}{*}{$\begin{array}{l}\text { Total No of papers } \\
\text { POLISH JOURNALS } \\
\text { Authors (with regards to their country of } \\
\text { origin) }\end{array}$} & \multicolumn{2}{|c|}{ SSM journals } & \multicolumn{3}{|c|}{ SSO journals } \\
\hline & \multicolumn{2}{|c|}{417} & \multicolumn{2}{|c|}{406} & \\
\hline & No of papers & $\%$ & $\begin{array}{l}\text { No of } \\
\text { papers }\end{array}$ & $\%$ & \\
\hline Polish authors & 58 & 13.9 & 228 & 56.2 & \\
\hline Authors - Central Europe (SK, CZ, HU) & 3 & 0.7 & 17 & 4.2 & \\
\hline Authors from the TOP 20 countries & 272 & 65.2 & 109 & 26.8 & \\
\hline Authors from the rest of the world & 173 & 41.5 & 90 & 22.2 & \\
\hline \multirow{3}{*}{$\begin{array}{l}\text { Total No of papers } \\
\text { HUNGARIAN JOURNALS } \\
\text { Authors (with regards to their country of } \\
\text { origin) }\end{array}$} & \multicolumn{2}{|c|}{ SSM journals } & \multicolumn{3}{|c|}{ SSO journals } \\
\hline & \multicolumn{2}{|c|}{114} & \multicolumn{2}{|c|}{362} & \\
\hline & No of papers & $\%$ & $\begin{array}{r}\text { No of } \\
\text { papers }\end{array}$ & & $\%$ \\
\hline Hungarian authors & 4 & 3.5 & 113 & 31.2 & \\
\hline Authors - Central Europe (SK, CZ, PL) & 1 & 0.9 & 26 & 7.2 & \\
\hline Authors from the TOP 20 countries & 105 & 92.1 & 118 & 32.6 & \\
\hline Authors from the rest of the world & 20 & 17.5 & 132 & 36.5 & \\
\hline
\end{tabular}

Source: http://thomsonreuters.com/web-of-science-core-collection/[accessible 20/10/2016].

As reported by the evaluation indicators of Thomson Reuters - Essential Science Indicators, the world's Top 20 countries in relation to the number of citations are ranked as follows: USA, Germany, England, Japan, France, Canada, China, Netherlands, Australia, Spain, Sweden, Switzerland, South Korea, Belgium, India, Scotland, Denmark, Israel, Brazil and Italy. A comparison of Top 20 countries is a common practice in many scholarly publications related to analysis of bibliometric data (Andreis and Jokić 2008; Laffan 2009; Bański 2012).

The share of articles by authors' country of origin does not represent 100 percent; nor does the sum of the number of articles give the resulting value of the category (referred in bold in Table 5). If an article was written for example by three authors from the Czech Republic, 
Slovakia and Germany, the article is counted three times (whole counting): once as an article by a Czech author, once in the group of authors from Central Europe, and once in the group of Top 20 (Germany).

Table 6 presents the values of the indicator of national orientation (INO) of Central European journals. Findings show that journals such as Central European Journal of Public Health (CZ), Advances in Cognitive Psychology (PL), Nordic Studies on Alcohol and Drugs (PL), International Journal of Occupational Safety and Ergonomics (PL), Eastern European Countryside (PL), Acta Economical (HU) and Across Languages and Cultures (HU) are with the INO values < 34 which reflect (inter) nationally oriented. The value of the indicator symbolizes the country with the highest proportion of articles. Relatively strong (inter) national orientation of the above mentioned journals could be explained by the acceptance of articles in English only, and the long-time indexation status in Web of Science, which corresponds to a sufficient period to transform them from nationally to (inter)nationally oriented periodicals. Journals belonged to Social Science - Public Health and Psychology (SSM) group have a higher rate of (inter) national orientation, compared to the group of journals in Social Science - others (SSO).

Table 6: INO Indicator Czech (CZ), Slovak (SK), Polish (PL) and Hungarian (HU) Journals Registered in WoS (2012 - 2015)

\begin{tabular}{|c|c|c|c|}
\hline Group of journals/titles & $\begin{array}{c}\text { INO } \\
\text { Indicator (\%) } \\
\end{array}$ & $\begin{array}{l}\text { Authors from the TOP } \\
20 \text { countries (\%) }\end{array}$ & $\begin{array}{c}\text { The most represented } \\
\text { country }\end{array}$ \\
\hline \multicolumn{4}{|l|}{$\begin{array}{l}\text { Journals registered in SSCI \& SCIE - Public health and } \\
\text { psychology } 2012-2015,(S S M)\end{array}$} \\
\hline CENTRAL EUROPEAN JOURNAL OF PUBLIC HEALTH (CZ) & 26.4 & 37.3 & Czech rep. \\
\hline CESKOSLOVENSKA PSYCHOLOGIE (CZ) & 65.6 & 9.1 & Czech rep. \\
\hline STUDIA PSYCHOLOGICA (SK) & 35.4 & 25.3 & Slovakia \\
\hline ADVANCES IN COGNITIVE PSYCHOLOGY (PL) & 32.3 & 90.8 & Germany \\
\hline NORDIC STUDIES ON ALCOHOL AND DRUGS (PL) & 32.8 & 57.8 & Sweden \\
\hline INTERNATIONAL JOURNAL OF OCCUPATIONAL SAFETY AND & 22.0 & 61.9 & Poland \\
\hline $\begin{array}{l}\text { ERGONOMICS (PL) } \\
\text { JOURNAL OF BEHAVIORAL ADDICTIONS (HU) }\end{array}$ & 39.5 & 92.1 & USA \\
\hline \multicolumn{4}{|l|}{$\begin{array}{l}\text { Journals registered in SSCI \& SCIE - others } 2012-2015, \\
\text { (SSO) }\end{array}$} \\
\hline $\begin{array}{l}\text { AGRICULTURAL ECONOMICS-ZEMEDELSKA EKONOMIKA } \\
\text { (CZ) }\end{array}$ & 39.2 & 33.8 & Czech rep. \\
\hline E \& M EKONOMIE A MANAGEMENT (CZ) & 55.1 & 5.1 & Czech rep. \\
\hline $\begin{array}{l}\text { FINANCE A UVER-CZECH JOURNAL OF ECONOMICS AND } \\
\text { FINANCE (CZ) }\end{array}$ & 45.9 & 30.6 & Czech rep. \\
\hline GEOGRAFIE (CZ) & 81.7 & 7.5 & Czech rep. \\
\hline MORAVIAN GEOGRAPHICAL REPORTS (CZ) & 55.8 & 8.1 & Czech rep. \\
\hline POLITICKA EKONOMIE (CZ) & 90.1 & 8.8 & Czech rep. \\
\hline PRAGUE ECONOMIC PAPERS (CZ) & 64.6 & 10.2 & Czech rep. \\
\hline $\begin{array}{l}\text { SOCIOLOGICKY CASOPIS-CZECH SOCIOLOGICAL REVIEW } \\
\text { (CZ) }\end{array}$ & 68.8 & 18.8 & Czech rep. \\
\hline SLOVO A SLOVESNOST (CZ) & 83.9 & 8.9 & Czech rep. \\
\hline EKONOMICKY CASOPIS (SK) & 54.5 & 5.2 & Slovakia \\
\hline SOCIOLOGIA (SK) & 53.4 & 7.8 & Czech rep. \\
\hline PROBLEMY EKOROZWOJU (PL) & 63.6 & 35.5 & Poland \\
\hline EASTERN EUROPEAN COUNTRYSIDE (PL) & 30.3 & 12.1 & Poland \\
\hline ARGUMENTA OECONOMICA (PL) & 61.0 & 11.9 & Poland \\
\hline POZNAN STUDIES IN CONTEMPORARY LINGUISTICS (PL) & 42.7 & 33.7 & Poland \\
\hline POLISH SOCIOLOGICAL REVIEW (PL) & 64.3 & 25.2 & Poland \\
\hline ACTA OECONOMICA (HU) & 23.2 & 29.0 & Hungary \\
\hline ACROSS LANGUAGES AND CULTURES (HU) & 18.5 & 68.5 & Belgium \\
\hline CIVIL SZEMLE (HU) & 56.4 & 17.0 & Hungary \\
\hline ACTA LINGUISTICA HUNGARICA (HU) & 39.0 & 33.9 & Hungary \\
\hline
\end{tabular}


Source: http://thomsonreuters.com/web-of-science-core-collection/ [accessible 20/10/2016].

The best score in the category Social Science - others (SSO) within the Czech Republic and Slovakia have reached two journal - Agriculture Economics (INO=39.2) and Sociology (INO=53.4). In Sociology, almost 50 percent of authors are affiliated to academic and scientific institutions in Czech Republic (Table 7). The most unfavorable score (INO>80) was obtained by journals such as Geography (INO=81.7) and Political Economy (INO=90.1). In these journals, more than 80 percent of the published articles during the observed period 2012 - 2015 were published in authorship or co-authorship with Czech authors. Moravian Geographical Reports is an example of a journal, when language is not a sufficient requirement for the status of (inter)national orientation. The journal published articles exclusively in English, but more than 55 percent of the articles belonged to Czech authors. Moreover, the concept of (inter)national orientation of most Central European social science journals must be understood with some controversy, because mostly articles are published by authors form "the nearest abroad" and not with the top 20 countries, as is a case of the majority of Anglo-Saxon publications indexed in the Web of Science.

\section{Selected Bibliometric Indicators of Performance Central European Journals Indexed in JCR Social Science Edition}

In the last decade, there have been developments in scientometrics methods that began to offer a range of more sophisticated indicators comparing the quality and evaluation of journals. Unlike the classical impact factor-modern indicators are not limited to the number of citations, the prestige of journal and total citations of article in other journals are also considered (Garfield 1985; Cronin 1998; Frank 2003; Epstein 2004; Brown 2007).

The ranking of Central European social sciences journals indexed in Web of Science in the years 2012-2015 is presented in Table 8. The average impact factor (IF) calculated by selfcitations of publication output per author was considered in the analysis. Although this indicator does not reflect the quality of published papers, there were journals identified whose IF value is based on self-citations from previous volumes. The Polish journal Problems of Sustainable Development (Problemy Ekorozwoju), with the highest average selfcitation IF 0.663 is a case in point.

When evaluating the journals based on their geographical region, it was found that Prague's (Hungary) Geography journal decreases in rating unlike the Brno's (Czech) Moravian Geographical Reports, in comparing the values of IF JCR (average). Slovak journals have lower IF if compared to the Central European journals' IF average value. At this point, however, it is noted that the low IF of Slovak journals is largely influenced by a limited number of those journals registered in the Web of Science. Some social sciences disciplines do not have their own journals, for example in the fields of social anthropology, social geography, linguistics and political sciences. However, an incentive for these disciplines is would be a situation where the editorial board members accepted papers of their academic colleagues from related disciplines, in the case of Journal of Economics and Sociology.

In the last column of Table 8, quartile rankings are derived for each journal in each of its subject categories according to which quartile of the IF distribution the journal occupies for that subject category (Rousseau 2005). Q1 denotes the top 25\% of the IF distribution, Q2 for middle-high position (between top 50\% and top 25\%), Q3 middle-low position (top 75\% to top $50 \%$ ), and Q4 the lowest position (bottom $25 \%$ of the IF distribution). Hungarian Journal of Behavioral Addictions has the highest rank in terms of journal quartile (Q2). 
Table 7: The Most Important Organizations with Authors' Affiliation of Articles $(2012-2015)$

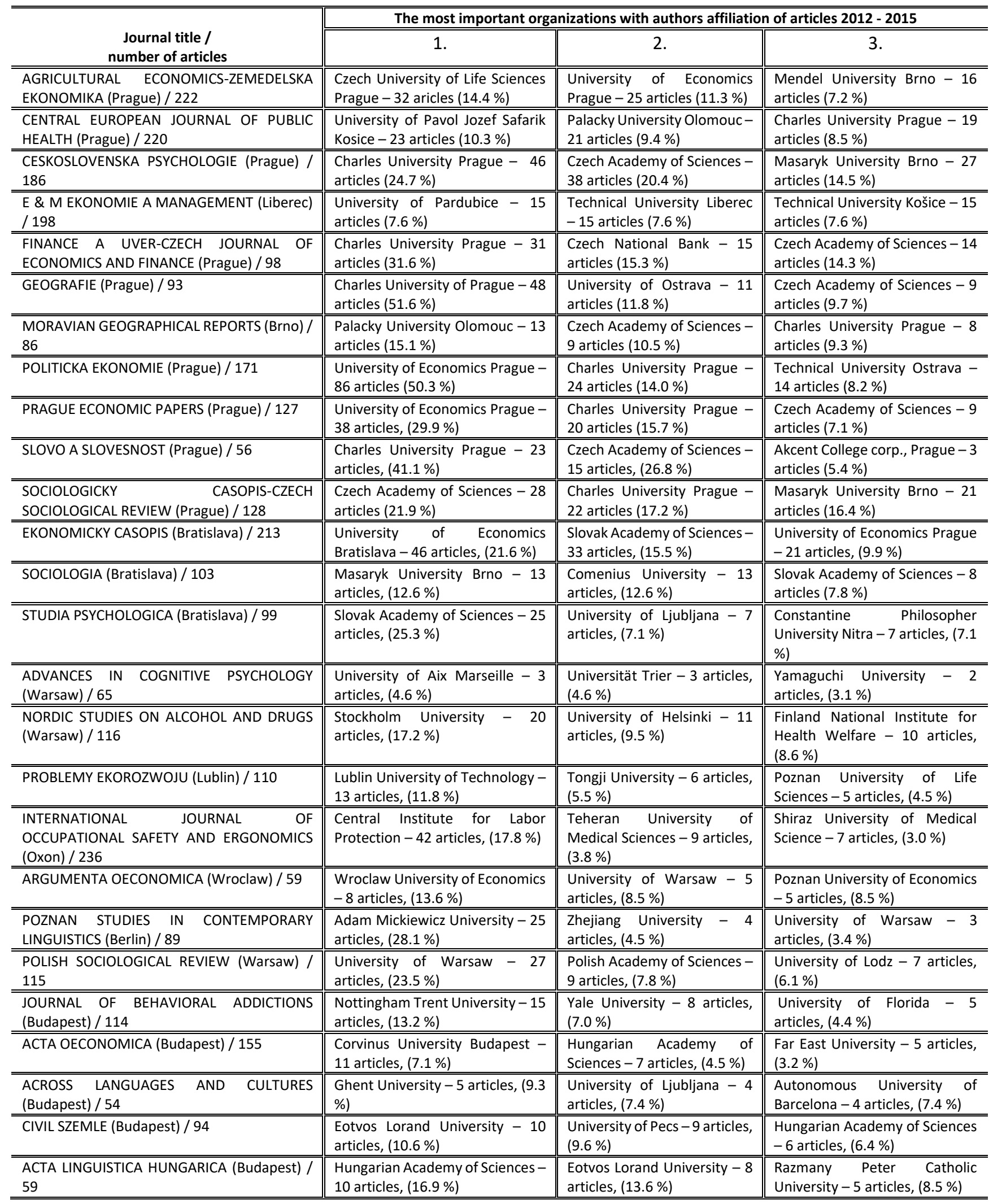

Source: http://thomsonreuters.com/web-of-science-core-collection/ [accessible 20/10/2016]. 
Table 8: Selected Journals Performance Indicators in the JCR Social Sciences Edition

\begin{tabular}{|c|c|c|c|c|}
\hline $\begin{array}{l}\text { Scientific field } \\
\text { /Journal title }\end{array}$ & ES & AIS & IF * & $\begin{array}{c}\text { JIF } \\
\text { Quartile }\end{array}$ \\
\hline \multicolumn{5}{|l|}{ Journals registered in SSCI \& SCIE - Public health and psychology (SSM) } \\
\hline CENTRAL EUROPEAN JOURNAL OF PUBLIC HEALTH (CZ) & 0.00077 & N/A & 0.084 & Q4 \\
\hline CESKOSLOVENSKA PSYCHOLOGIE (CZ) & 0.00009 & 0.023 & 0.195 & Q4 \\
\hline STUDIA PSYCHOLOGICA (SR) & 0.00026 & 0.112 & 0.124 & Q4 \\
\hline ADVANCES IN COGNITIVE PSYCHOLOGY (PL) & 0.00091 & N/A & 0.025 & Q3 \\
\hline NORDIC STUDIES ON ALCOHOL AND DRUGS (PL) & 0.00036 & N/A & 0.183 & Q4 \\
\hline INTERNATIONAL JOURNAL OF OCCUPATIONAL SAFETY AND & 0.00060 & 0.163 & 0.052 & Q4 \\
\hline \multicolumn{5}{|l|}{ ERGONOMICS (PL) } \\
\hline JOURNAL OF BEHAVIORAL ADDICTIONS (HU) & 0.00054 & 0.517 & 0.395 & Q2 \\
\hline \multicolumn{5}{|l|}{ Journals registered in SSCI \& SCIE - others 2012 - 2015, (SSO) } \\
\hline AGRICULTURAL ECONOMICS-ZEMEDELSKA EKONOMIKA (CZ) & 0.00036 & 0.075 & 0.159 & Q4 \\
\hline E \& M EKONOMIE A MANAGEMENT (CZ) & 0.00021 & 0.064 & 0.236 & Q3 \\
\hline FINANCE A UVER-CZECH JOURNAL OF ECONOMICS AND FINANCE (CZ) & 0.00026 & 0.123 & 0.137 & Q4 \\
\hline \multirow[t]{2}{*}{ GEOGRAFIE (CZ) } & 0.00021 & 0.117 & & Q4 \\
\hline & & & 0.228 & \\
\hline MORAVIAN GEOGRAPHICAL REPORTS (CZ) & 0.00018 & N/A & 0.108 & Q3 \\
\hline POLITICKA EKONOMIE (CZ) & 0.00026 & 0.079 & 0.322 & Q3 \\
\hline PRAGUE ECONOMIC PAPERS (CZ) & 0.00017 & 0.089 & 0.061 & Q3 \\
\hline SOCIOLOGICKY CASOPIS-CZECH SOCIOLOGICAL REVIEW (CZ) & 0.00035 & 0.125 & 0.234 & Q3 \\
\hline SLOVO A SLOVESNOST (CZ) & 0.00005 & 0.044 & 0.270 & Q4 \\
\hline EKONOMICKY CASOPIS (SR) & 0.00022 & 0.048 & 0.097 & Q4 \\
\hline SOCIOLOGIA (SR) & 0.00009 & 0.184 & 0.114 & Q4 \\
\hline PROBLEMY EKOROZWOJU (PL) & 0.00023 & 0.120 & 0.663 & Q4 \\
\hline EASTERN EUROPEAN COUNTRYSIDE (PL) & 0.00002 & 0.026 & 0.044 & Q4 \\
\hline ARGUMENTA OECONOMICA (PL) & 0.00009 & 0.021 & 0.114 & Q4 \\
\hline POZNAN STUDIES IN CONTEMPORARY LINGUISTICS (PL) & 0.00022 & 0.103 & 0.027 & Q4 \\
\hline POLISH SOCIOLOGICAL REVIEW (PL) & 0.00010 & 0.042 & 0.014 & Q4 \\
\hline ACTA OECONOMICA (HU) & 0.00011 & 0.075 & 0.225 & Q4 \\
\hline ACROSS LANGUAGES AND CULTURES (HU) & 0.00016 & 0.150 & 0.019 & Q4 \\
\hline CIVIL SZEMLE (HU) & 0.00002 & 0.008 & 0.118 & Q4 \\
\hline ACTA LINGUISTICA HUNGARICA (HU) & 0.00023 & 0.164 & 0.036 & Q4 \\
\hline
\end{tabular}

* Journal self- citation

Source: http://thomsonreuters.com/web-of-science-core-collection/ [accessible 20/10/2016].

The Eigenfactor metrics in relation to IF do not include journal self-citations, moreover honor citations of highly represented worldwide journals (Yin 2011; Jacso 2012), which is reflected in the values of Eigenfactor Score (ES) and Article Influence Score (AIS) indicators in the observed period (Table 8). Almost all Central European journals have ES and AIS values, however the values are significantly lower than their IF values. It indicates that their influence on the world scientific community is less than would be expected if compared to their impact factor values. For the coverage period 2012 - 2015, Journal of Behavioral Addictions (0.517, Hungary) was ranked first based on AIS. Skovajsa (2014b) reported that the AIS values for Czech journals are still very low compared to leading Western journals, however, in some Central European journals there are tendencies to overcome other regional journals in the AIS score. Unfortunately, AIS score is dependent on citations in the top international journals worldwide.

In addition, some Central European journals also obtain other impact indicator values such as Immediacy index and Aggregate immediacy index. The Immediacy Index expresses the average number of times an article is cited in the various Web of Science journals in the year it is published (Huang and Lin 2012). It indicates how quickly articles in a journal is cited. The Aggregate Immediacy Index on the other hand indicates how quickly articles in a subject category are cited. Their values from year to year can vary considerably, and because it is a 
per-article average, the immediacy index tends to discount the advantage of large journals over small ones. Frequently issued journals and the "Online First" platform may have an advantage because an article published early in the year has a better chance of being cited that the one published later in the year. Many publications that publish infrequently or late in the year have low immediacy index. For this reason, the study does not take further investigation on these indicators because they have lower scientometrics significance in comparison with other journal impact indicators.

\section{CONCLUSION}

This paper has presented the assessment of Central European journals covered in the Web of Science database and JCR focusing on social science disciplines. The impact factor of the journals appears as an internationally recognized indicator for evaluating the quality of the journals and their articles. It has initially been used by libraries for journal assessment and it influences subscription decisions. In addition, impact factor has also been perceived as the "Golden standard" when determining research quality, comparing performance of academic staff, research institutions, university departments.

In the past few years, however, more and more voices (e.g. Bajerski and Siwek 2012; Shao and Shen 2014) drew the attention of the scholarly community to the shortcomings of this indicator and proposed taking account of the other bibliometric indicators in the evaluation of journals, such as the average 5-year journal IF, Eigenfactor Score (ES) and Scimago Journal Rank (SJR). Eigenfactor indicator does not count self-citation of journal, but on the contrary, prefers citations from highly ranked journals (usually with international orientation), that weighted to make a larger contribution to the eigenfactor than those from poorly ranked journals. Similarly, the SJR indicator assigns different values to citations depending on the importance of the journals where they come from. This way, citations coming from highly important journals will be more valuable and hence will provide more prestige to the journals receiving them. SJR, developed by the Spain research organization Scimago, became the decisive criterion for ranking journals in Scopus database.

Because of the changes in the journal selection and evaluation policy of Clarivate Analytics (previously the Intellectual Property and Science business of Thomson Reuters) in 2016, a list of new, mainly regional journals from Central and Southeastern Europe have been included for indexation in the Web of Science. This procedure has ultimately brought an impact to scholarly publishing in neighboring countries - there is an increase in the number of impact-factored journals in Czech Republic to eleven (11), eight (8) in Poland, and five (5) in Hungary. This has created a competitive environment for social science researchers, especially those who have their competitors in neighboring countries such as in the fields of psychology, economy, geography, and sociology. Slovakia unfortunately has not contributed significantly to the new initiative and the number of impact-factored social science journals remained the same (3). Competitiveness between journals may occur in the next few years and could improve the relative position of IF journals, since authors can cite their papers or their colleagues' papers in various related scientific disciplines.

Newly indexed journals have a worse starting position in obtaining a comparable number of citations than their older competitors in the scholarly communication environment, but there are also exceptions such as the Moravian Geographical Reports, when in 2014 and 2015 reached above-average IF within the Central European's social science journals. 
The aim of paper has been brought forward to consideration about the possibility of wider opening of Central European journals to the international scientific community. For this purpose, selected bibliographic data are analysed: journal title and author's affiliation, number of published articles, the number and percentage of articles published in different languages, the total number and percentage of articles per country of authors/co-authors' origin and their share in the total number of published articles, as well as index of national orientation. Significant attention has been paid to comparing self-citation impact factor score by the relevant scientific discipline in the Web of Science, JCR rank of the journals as well as average article impact in the journal measured for five years after its publication.

Evaluation of journals by their country indicates that Czech Republic, as a country of origin for authorship of publication in the social sciences, is the most represented country in all journal categories, either as a single author or co-authors of articles, followed by Slovak, Hungarian and Polish authors. Furthermore, for all journals categories, the domestic or country-based authors contributed the most, followed by authors from other regions. However, despite the domination of national journals orientation, if considered the country of origin of authors, journals included in category SSM show a higher international orientation in all key indicators of the study - by language title of journal and published articles. Indicator of national orientation (INO) of Central European journals have revealed that only journals belong to SSM group - Central European Journal of Public Health and the International Journal of Occupation Safety and Ergonomics (INO<34) are (inter)nationally oriented. Journals in the category social sciences - Public health and psychology (SSM) showed a higher rate of (inter)national orientation compared to the other category of social science journals (SSO). Enhancement of the Central European journals registered in the Web of Science database could engage national scientific policy institutions to encourage national journals to be more responsible and more involved in (a) controlling their editorial practices; (b) advocating openness to foreign authors; (c) including mono-thematic issues; (d) using a combination of publishing in both the local language and in English; and (e) encouraging more involvement and participation by academics and researchers to publish their work jointly with regional co-authors, besides those from Top 20 countries (Andreis and Jokić 2008).

\section{ACKNOWLEDGEMENT}

This research received no specific grant from any funding agency in the public, commercial, or not-for profit sectors.

\section{REFERENCES}

Abrizah A., Xu J., and Nicholas D. 2017. Scholarly communication and matters of trust and authority: A comparative analysis of Malaysian and Chinese researches. Malaysian Journal of Library \& Information Science, Vo. 22, no. 3: 69-91.

Andreis, M. and Jokić, M. 2008. An impact of Croatian journals measured by citation analysis from SCl-Expanded database in time span 1975-2001. Scientometrics, Vol. 75, no. 2: 263288.

Bajerski, A. and Siwek, T. 2012. The bibliometric analysis of Czech geography in the Scopus database. Geografie, Vol. 117, no. 1: 52-71. 
Bucher, $S$.

Bański, J. 2012. The position of geography in the organizational structure of selected academic institutions around the world. Polish Geographical Review, Vol. 84, no. 2: 1992017.

Bar-llan, J. 2008. Which h-index? A comparison of WoS, Scopus and Google Scholar. Scientometrics, Vol. 74, no. 2: 257-271.

Bloch, S. and Walter, G. 2001. The impact factor: time for a change. Australian and New Zealand Journal of Psychiatry, Vol. 35, no. 5: 563-568.

Bosman, J. 2009. The changing position of society journals in Geography. Tijdschrift voor Economische en Sociale Geografie, Vol. 100, no. 1: 20-32.

Brown, H. 2007. How impact factors changed medical publishing - and science. British Medical Journal, Vol. 334, no. 7593: 561-564.

Cronin, B. 1998. Metatheorizing citation - Comments on theories of citation? Scientometrics, Vol. 43, no. 1: 45-55.

Epstein, R. J. 2004. Journal impact factors do not equitably reflect academic staff performance in different medical subspecialities. Journal of Investigative Medicine, Vol. 52, no. 8: 531-536.

Frank, M. 2003. Impact factors: arbiter of excellence? Journal of the Medical Library Association, Vol. 91, no. 1: 4-6.

Garfield, E. 1985. In Tribute to Derek John de Solla Price: A Citation analysis of little science, big sicence. Scientometrics, Vol. 7, no. 3-6: 487-503.

Garfield, E. 2006. The history and meaning of the Journal Impact Factor. JAMA, Vol. 295, no. 1: 90-93.

Huang, M. H. and Lin, W. Y. C. 2012. The influence of journal self-citations on impact factor and immediacy index. Online Information Review, Vol. 36, no. 5: 639-654.

Hicks, D. 1999. The difficulty of achieving full coverage of international social science literature and the bibliometric consequences. Scientometrics, Vol. 44, no. 2: 193-215.

Hofierka, J. and Gallay, M. 2013. Publication activities of geography departments at Slovak universities in the period of 2007 - 2013. Geographia Cassoviensis, Vol. 7, no. 2: 22-30.

Jacso, P. 2012. The problems with the subject categories schema in the EigenFactor database from the perspective of ranking journals by their prestige and impact. Online Information Review, Vol. 36, no. 5: 758-766.

Jurajda S., Kozubek S., Munich D., and Skoda S. 2017. Scientific publication performance in post-communist countries: still lagging far behind. Scientometrics, Vol. 112, no. 1: 315328.

Laffan, S.W. 2010. The citation relationships between journals of geography and cognate disciplines. Geographical Research, Vol. 48, no. 2: 166-180.

Machaček, M. and Kolcunova, E. 2008. Hirsch index and rankings of Czech economists. Politicka ekonomie, Vol. 56, no. 2: 229-241.

Makkonen T. and Mitze T. 2016. Scientific collaboration between 'old' and 'new' member states: Did joining the European Union make a difference? Scientometrics, Vol. 106, no. 3: 1193-1215.

Maričić, S., Sorokin, B. and Papeš, Z. 2000. Croatian journals at the end of the 20 century: A bibliometric evaluation. Journal for general social issues, Vol. 9, no. 1: 1-17.

Maričić, S. 2007. Scholarly journals from the scientific periphery - towards a common methodology for evaluating their scientific communicability? Vjesnik Bibliotekara Hrvatske, Vol. 50, no. 1-2: 62-78.

Mayur, A. and Mabe, M. 2004. Impact factors: Its use and misuse. Pokroky matematiky, fyziky a astronomie, Vol. 49, no. 4: 281-288.

Meho, L. I. and Yang, K. 2007. A new era in citation and bibliometric analyses: Web of Science, Scopus, and Google Scholar. Journal of the American Society for Information Science and Technology, Vol. 58, no. 13: 2105-2125. 
Moed, H. F. 2005. Citation analysis in research evaluation. Dordrecht: Springer.

Moed, H.F. 2010. Measuring contextual citation impact of scientific journals. Journal of Informetrics, Vol. 4, no. 3: 265-277.

Nederhof, A.J. 2006. Bibliometric monitoring of research performance in the social sciences and the humanities: A review. Scientometrics, Vol. 66, no. 1: 81-100.

Pulišelić, L. and Petrak, J. 2006. Is it enough to change the language? A case study of Croatian biomedical journals. Learned Publishing, Vol. 19, no. 4: 299-306.

Rousseau, R. 2005. Median and percentile impact factors: A set of new indicators. Scientometrics, Vol. 63, no. 3: 431-441.

Shao, J.F. and Shen, H.Y. 2014. Academic impact of Chinese medical journals in the Web of Science, 2009-2012. Current Science, Vol. 107,no. 11: 1854-1858.

Siwek, T. 2005. The bibliometric analysis of Czech geography in the Scopus database. Geografie, Vol. 110, no. 2: 116-117.

Skovajsa, M. 2014a. Total and foreign-journal citedness of Czech Sociological Review: The results of a citation analysis. Sociologicky časopis / Czech Sociological Review, Vol. 50, no. 5: 671-712.

Skovajsa, M. 2014b. Místo Sociologického časopisu/Czech Sociological Review mezi sociologickými časopisy podle bibliometrických indikatorů. Úvaha nepřiliš jubilejní. Sociologicky časopis / Czech Sociological Review, Vol. 50, no. 5: 759-778.

Tang, CY., Zhang GY., and Naumann SE. 2017. Do central authors of international coauthored publication networks obtain a high research impacts? Malaysian Journal of Library \& Information Science, 22(3), 1-17.

Vanclay, J. K. 2012. Impact Factor: Outdated artefact or stepping-stone to journal certification? Scientometrics, Vol. 92, no. 2: 211-238.

Varela, D. 2013. The Contribution of ISI Indexing to a Paper's Citations: Results of a Natural Experiment. European Political Science, Vol. 12, no. 2: 245-253.

Yin, C.Y. 2011. Do impact factor, h-index and Eigenfactor (TM) of chemical engineering journals correlate well with each other and indicate the journals' influence and prestige? Current Science, Vol. 100, no. 5: 648-653.

Zitt, M. and Bassecoulard, E. 1998. Internationalization of scientific journals: A Measurement based on publication and citation scope. Scientometrics, Vol. 41, no. 1-2: 255. 
Appendix: Central European Journals Indexed in the Social Science Citation Index (2012 - 2015)

\begin{tabular}{|c|c|c|c|c|c|c|}
\hline Journal title & $\begin{array}{l}\text { Scientific } \\
\text { field }\end{array}$ & $\begin{array}{l}\text { Indexation } \\
\text { Year in WoS }\end{array}$ & $\begin{array}{l}\text { Head office of } \\
\text { the publisher }\end{array}$ & Name of Publisher & $\begin{array}{l}\text { Number of } \\
\text { articles }\end{array}$ & $\begin{array}{l}\text { Subject category in } \\
\text { WoS }\end{array}$ \\
\hline AGRICULTURAL ECONOMICS-ZEMEDELSKA EKONOMIKA & SSO & 2007 & Prague (CZ) & CZECH ACADEMY AGRICULTURAL SCIENCES & 222 & Economy \\
\hline CENTRAL EUROPEAN JOURNAL OF PUBLIC HEALTH & SSM & 2011 & Prague (CZ) & $\begin{array}{l}\text { NATL INST PUBLIC HEALTH, DEPT SCIENTIFIC } \\
\text { INFORMATION }\end{array}$ & 220 & Public health \\
\hline CESKOSLOVENSKA PSYCHOLOGIE & SSM & 1985 & Prague (CZ) & ACADEMIA, PUBL HOUSE CZECH ACAD SCI & 186 & $\begin{array}{l}\text { Psychology, } \\
\text { Multidisciplinary }\end{array}$ \\
\hline E \& M EKONOMIE A MANAGEMENT & SSO & 2008 & Liberec (CZ) & $\begin{array}{l}\text { TECHNICKA UNIV \& LIBERCI, HOSPODARSKA } \\
\text { FAKULTA }\end{array}$ & 198 & Economy, Management \\
\hline FINANCE A UVER-CZECH JOURNAL OF ECONOMICS AND FINANCE & SSO & 1998 & Prague (CZ) & $\begin{array}{l}\text { CHARLES UNIV-PRAGUE } \\
\end{array}$ & 98 & Business, Finance \\
\hline GEOGRAFIE & SSO & 2008 & Prague (CZ) & CZECH GEOGRAPHIC SOC, CHARLES UNIV & 93 & Geography \\
\hline MORAVIAN GEOGRAPHICAL REPORTS & SSO & 2011 & Brno (CZ) & ACAD SCI CZECH REPUBLIC, INST GEONICS & 86 & Geography \\
\hline POLITICKA EKONOMIE & SSO & 1985 & Prague (CZ) & VYSOKA SKOLA EKONOMICKA & 171 & Economy, Politics \\
\hline PRAGUE ECONOMIC PAPERS & SSO & 2008 & Prague (CZ) & $\begin{array}{l}\text { UNIV ECONOMICS-PRAGUE, OECONOMICA } \\
\text { PUBL }\end{array}$ & 127 & Economy \\
\hline SLOVO A SLOVESNOST & SSO & 2009 & Prague (CZ) & CZECH LANG INST CZECH ACAD SCI & 56 & Linguistics \\
\hline SOCIOLOGICKY CASOPIS-CZECH SOCIOLOGICAL REVIEW & SSO & 1985 & Prague (CZ) & SOCIOLOGICKÝ ÚSTAV AV ČR & 128 & Sociology \\
\hline EKONOMICKY CASOPIS & SSO & 1985 & Bratislava (SK) & SLOVAK ACADEMIC PRESS LTD & 213 & Economy \\
\hline SOCIOLOGIA & SSO & 1994 & Bratislava (SK) & SLOVAK ACADEMIC PRESS LTD & 103 & Sociology \\
\hline STUDIA PSYCHOLOGICA & SSM & 1985 & Bratislava (SK) & $\begin{array}{l}\text { SLOVAK ACAD SCIENCES INST } \\
\text { EXPERIMENTAL PSYCHOLOGY }\end{array}$ & 99 & Psychology \\
\hline ADVANCES IN COGNITIVE PSYCHOLOGY & SSM & 2012 & Warsaw (PL) & UNIV FINANCE \& MANAGEMENT & 65 & $\begin{array}{l}\text { Experimental } \\
\text { psychology }\end{array}$ \\
\hline NORDIC STUDIES ON ALCOHOL AND DRUGS & SSM & 2011 & Warsaw (PL) & DE GRUYTER OPEN LTD & 116 & Drugs \\
\hline PROBLEMY EKOROZWOJU & SSO & 2008 & Lublin (PL) & POLITECHNIKA LUBELSKA & 110 & Environment \\
\hline $\begin{array}{l}\text { INTERNATIONAL JOURNAL OF OCCUPATIONAL SAFETY AND } \\
\text { ERGONOMICS }\end{array}$ & SSM & 2006 & Oxon (UK) & TAYLOR \& FRANCIS LTD & 236 & $\begin{array}{l}\text { Ergonomics, Public } \\
\text { health }\end{array}$ \\
\hline EASTERN EUROPEAN COUNTRYSIDE & sso & 2007 & Torun (PL) & $\begin{array}{l}\text { WYDAWNICTWO UNIWERSYTETU MIKOLAJA } \\
\text { KOPERNIKA }\end{array}$ & 33 & Sociology \\
\hline ARGUMENTA OECONOMICA & SSO & 2008 & Wroclaw (PL) & WROCLAW UNIV ECONOMICS & 59 & Economy \\
\hline $\begin{array}{l}\text { POZNAN STUDIES IN CONTEMPORARY LINGUISTICS } \\
\end{array}$ & SSO & 2008 & Berlin (D) & DE GRUYTER MOUTON & 89 & Linguistics \\
\hline $\begin{array}{l}\text { POLISH SOCIOLOGICAL REVIEW } \\
\end{array}$ & SSO & 2006 & Warsaw (PL) & POLISH SOCIOLOGICAL ASSOC & 115 & Sociology \\
\hline JOURNAL OF BEHAVIORAL ADDICTIONS & SSM & 2012 & Budapest (HU) & AKADEMIAI KIADO RT & 114 & Psychiatry \\
\hline ACTA OECONOMICA & SSO & 1985 & Budapest (HU) & AKADEMIAI KIADO RT & 155 & Economy \\
\hline ACROSS LANGUAGES AND CULTURES & SSO & 2008 & Budapest (HU) & AKADEMIAI KIADO RT & 54 & Linguistics \\
\hline CIVIL SZEMLE & SSO & 2007 & Budapest (HU) & UJ MANDATUM KONYVKIADO & 94 & Public health \\
\hline ACTA LINGUISTICA HUNGARICA & SSO & 2007 & Budapest (HU) & AKADEMIAI KIADO RT & 59 & Linguistics \\
\hline
\end{tabular}

Notes: SSM - Social Sciences: Medicine; SSO - Social Sciences: Others 